\title{
IDENTITY AND CULTURE CHANGE OF JAVANESE IN JOHOR
}

\author{
Mifedwil Jandra ${ }^{1}$, Agus Sulaiman Djamil2, Hussin Salamon ${ }^{2}$, Anhar Ansyory*33 Moh. Damami Zein4 \\ ${ }^{I}$ Centers of Research and Community Engagement (LPPM), Islamic State University of Sunan Kalijaga Yogyakarta \\ jandraj6@gmail.com \\ ${ }^{2}$ Faculty of Islamic Civilization, University Technology of Malaysia, agus.djamil@yahoo.com ; drhussin@utm.my \\ ${ }^{3}$ FTDI Universitas Ahmad Dahlan Yogyakarta, anharanshori52@gmail.com \\ 4 Ushuludin Faculty of Islamic State University of Sunan Kalijaga Yogyakarta
}

*Corresponding author anharanshori52@gmail.com

\begin{abstract}
Article history
Received:14/09/2015 Received in revised form:14/09/2015

Accepted: 18/10/2015

Abstract

The Javanese ethnics are among the largest population group in Johor. According to the history, they came to Johor as part of the suggestion and efforts by Temenggong Daing Ibrahim (1810-1862) when they opened the Gambir plantation in Johor back in 1830s after the failure of Gambir companies in Singapore due to lack of land area and fire-wood fuel. The main reason to bring the Javanese and Chinese workers or coolies to operate the Gambir plantation was through the kankar system which he introduced. Data and information were collected from interview with Javanese and books, as well as from journals and websites. The increase of Javanese population is due to their growth and increase of number of labour in Malaysia. Their present may cause several challenges including social and cultural identity. This study aim to understand the fundamental Javanese character and identity, how this identity has been integrated and blended into the Malays culture, and finally to identify the Javanese characters and identity that contribute to the changes in the local culture. The study found that the high tolerances and adaptability of the Javanese has contributed to the acceptance and social harmony to the existing ethnics in Johor.
\end{abstract}

Keywords: Java community, identity, cultural change 


\subsection{INTRODUCTION}

Johor population aggregated from several sub-ethnic Malays. The largest percentage is the Javanese origin. However, not all of them were coming from the marhein, or farmer-origin, Javanese from the Java Island. There are from the well-educated Islamic teacher, preacher as well as farmers. One of their migratory reasons is the limited availability of land in Java Island. Nowadays, they become part of successful and well-to-do Johor communities. Most of their children attained higher education and later worked in the public sector in Johor and the Federal Government. (Tun Sheikh, 2012).

Historically the first arrival of the Javanese to Johor were due to efforts by Temenggong Daing Ibrahim (1810-1862) when he need to open Gambir plantation in Johor in 1830s, after unsuccessful Gambir companies in Singapore due to lack of land plot and wooden fuel. The main reason to bring the Javanese and Chinese workers or coolies to operate the Gambir plantation was through the kankar system which he introduced. (Tun Sheikh, 2012).

From the physical posture, the Javanese have light-dark completion, medium-suize build and sturdy, hence softspoken. The Javanese is one of the longest dwelling ethnic in Johor. At the beginning, most of the Javanese centered in the northern side of the Malay Peninsula, especially in western coast of Johor, Selangor and Perak. The first site was believed to be around Padang, Parit Jawa, Muar. Most of the Javanese migrant to the Malay land came from several places in Java Island such as Jawa Barat, Central Java and East Java towns like Madiun, Ponogoro, Kudrejo, Lebumin, Demek and Magelang. (Hisham, 2012).

The Javanese during 1960's, may be recognized by their unique names like Suparji, Wagiman, Supendi, Masjoyo, Mulio, Karto, and Toliban for males and the female's name like Supinah,Tukijah, Jumiton, and Tukiyem. They also like to called their peer by the nickname, like: Man Ganden, Amat Ireng, Leman Gundol, Mbah Lanang and Nyai Cilik. But those nickname were obsolute when time goesby.(Etnik Jawa, 2013).

\subsection{INTRINSIC CHARACTERS OF JAVANESE}

The Javanese initially migrated to Malay land in the 1800s. There are many factors behind this Javanes migration to Johor. Among them are the suggestion and efforts by Temenggong Daing Ibrahim. After the Gambir company in Singapore fail due to lack of land plot for plantation and shortage of woods for fuel, those Javanese workers were taken across the strait to Johor by Syarikat Konstantinople belong to Arab millioner As Sagof who obtained concession in Pontian to open new plantation. There are also people form Java who independently migrated took refuge to Malay Land to start a new life circumvented the Dutch colonial rule on Culture Stelsel or forced agriculture in Java. Those who were muslim choose Johor as their new homeland, as Islam was prosper in Johor. The places in Johor where the Janavese population gathered most were Pontian, Batu Pahat dan Muar. (Hisham, 2012).

The character of Javanese were identified as polite attitude, reserves, suppressing or hiding their true feeling or avoid talking direct and very cautious on conversation ethics. They are very respectful to elders and putting weight on advises from elders. The Javanese languages have several hierarchies, and being used according to what subject is being conversed. The Javanese commonly like to suppressed their emotion. They tend to not express affectation, and value the gentleness and politeness as high ethics. For instance, while being hosted in a dinner function, they wait until being invited by the host first. The Javanese face difficulty to resist or say no to any request. This is all because keeping feeling in harmony and keeping out others form hurt feeling is the utmost important to them.

The Javanese value the ethic as very pricey. The young must speaks in very polite word of higher hierarchy Javanese Language when the talk to the elder. The same message can be conveyed in lower hierarchy Javanese language when he speaks to their same-age peers or younger. This include their conduct and manner. The younger person must take this respectful ethic seriously, and the Javanese has specific term for this called Ngajeni, or full respect. Other specific ethical principle strongly held 
by Javanese is Narimo ing pandum which mean acceptance to what you have. This character show the life principle to the total submission to whatever God has given them. (Hisham, 2012).

Javanese belief that all of this worldly life has been given, ordered and can not be repudiated. Every thing that happened to them has been believed comes from the will of God. Men cannot avoid, nor against the fate. This is the fate of life, and consider as the secret of God. They understand that all what has happened were ordered and by the will of God. Their way of life is truly unique. Should we understand their way of thinking, we should take many positive values. To the Javanese, God has planned and ordered all living creatures, including human being (Tun Sheikh, 2012).

The way of life concept of nerimo ing pandum (ora ngoyo) or accept what you are given, indicate that the Javanese seem to life without high ideal or goal. They don't need to aim high that not realistic. They do not suggest that. People may change for betterness, but not at accelerated pace. The Javanese called this 'relax' attitude with term ojo ngoyo, which means do not too forcefull. Ngoyo mean forcing yourself hard to do something. As they believe if you force things too much, it may evoke bad things to you, such as sickness. The sickness occurred due to forcing beyond the limit of real human capacity given to you. (Hisham, 2012).

The way of life of Javanese has been adopted from their ancestors. This heritage has been kept and uphold for generations. But how that values can be maintained throughout generations? It is because the practice them in their daily life. Such as the way of working in communal, known as gotong-royong, remain practiced till today. Javanese uphold idiom such as ringan sama dijinjing, berat sama dipikul, carry light things together, and shoulder heavy burden together (Hisham, 2012). This is awareness responsible principle of communal living.

We recognize that the Javanese way of live is pretty specific, quite distinctive relative to the other ethnic in the Indonesian archipelago. Their communal and ethnic cohesion is very strong, so helping each other has become something important. They help each other whoever need assistance. Often their efforts to help others goes to every means possible. This is even true if it relates to relatives or friends. The Javanese putting weight on positive values in their life. They always control their words and conduct in interacting within their community so they will eliminate chances to hurt others feeling. Comradeship and solidarity among fellow Javanese is very important.

They do not like to see others or themselves hurts or irritated by someone's remarks or deeds, because for them there is saying ajining diri soko lathi, ajining rogo soko busono which means 'someone's dignity emanate from their tounge (words or remarks) while the physical poise emanate from its attires. (Ihwan, 2013).

\subsection{POST MALAY INTEGRATION OF JAVANESE IDENTITY}

According to Clifford Geertz (1956), The Javanese society in Java Island is classified into three main social classes which are abangan, santri dan priyayi. Nevertheless, the Javanese community in Malaysia did not much care about the stratified class of ethnics. The Javanese poses several social system that group. Their communities were led by Head of Village in the rural area. The leader (Pak Lurah) play very important and crutial roles among its villagers, especially in keeping balance and strong solidarity. The head of community in Java known as Lurah dan Kiai. Lurah is also penghulu within the society, He will be responsible and carry an enormous amanah or trust to ensure that the villages are happy in live in harmony. Normally, appointment of Lurah in the village in Java were selected and appointed based on the capability, experience, decendance and the religious knowledge. The Lurah will be assisted by several right persons in running the administration of the village.

Other that keeping the village safe and secure, Lurah also play important role leadership roles for villages activities communal work (gotong royong) and other social activities. Beside Lurah, there are senior officer like Kiai or Siak. Kiai appointed among veteran males who are knowledgeable in Islam knowldge and social \& tradition. Kiai is repsonsible to lead prayer or Imam ini Masjid or mosques. Kiai also reponsible to lead thanksgiving and religious functions in the villages. He also need to be able to give islamic judgment. While during the funeral, the Kiai must be able to lead prayers. This social roles is a previledge and respect to Kiai. (Prof. Dr. Simuh, 2000). 
In Johor, the head of the village is known as Penghulu and matters that are related to the administration and safety are the responsibilities of the leaders. Javanese people always stays with their group and some identified areas that are conisist of many Javanese living, such as Parit Jawa, Muar, Pontian District and Sri Medan, and Batu Pahat. It can be seen based on my own experience of living in Batu Pahat, Johor. Because of many Javanese who are married to the Malay, Johor, their number increased from time to time. According to the breakdown of statistics pembacian State Statistics Department, Johor (2010), the Malays are as much as 48\%, China 40\%, India 8\% etc. of 4\%. The Malays fraction of the total of $48 \%$ is $50 \%$ Javanese, Bugis Malay quarter 12\%, 30\% etc. Johor Malay $8 \%$, (Ihwan, 2013). This shows that the majority of society is a society in Johor.

As described form the first content and the background, the identity or nature of Javanese are very good and ethical. After a long time Javanese community has been settled in Malaysia and became a Malaysia community, that isn't denied about the identity, gradually faded by the current flow. However, there is also a society that are still retain their identity as people Javanese. As an example, my mother was a child of Javanese, who married my father, who is a Malay of Johor. Indirectly, the language used during the conversation was in Bahasa Melayu.This is because my father's lack of understanding of the Java language.

Still, Javanese language are barely used in my family.However, others with a conversation between gammers and my mother, they often use the Java language when speaking and makes us keen to learn Java language. Even though it's not fluent in this language, but we can still understand the contexts of the conversations based on simple sentences that are used. Undeniably, the Java community are trying to maintain their identity as Javanese. Among the methods that are used, is to constantly using Java language, as the language to guide and keep manners, and ethics even when they are somewhere

As has been mentioned that the Javanese like to help each other in their communal life, this attitude expressed in many social functions and ceremonies such as rewang or preparation for wedding, sunatan or boy-circumcision, lenggang perut et cetera. These tradition brought along by Javanese and still practiced in Johor like: lenggang perut, bengkongan, puputan or cukur jambul, sunatan atau berkhatan, baraan or ziarah raya, rewang or gotong-royong and nasi ambeng or ambang. After decades pasts, these ceremonies and traditions were adopted by the indigenous Malays society. This adoptions indicated how the Javanese culture has been assimilated into the Malay culture.

In the other hand, naturally the Malay culture and tradition that being adopted by the Javanese migrant as they had life in generations. This assimilation indicated that the Javanese has been accepted as part of the Malay society and the Javanese tradition become part of Malay tradition. But the way the Javanese talk in Malay still recognizable especialy among the elders who have very thick (medhok) Javanese accents. Tehey still use Javanese language as their mother tounge and use it in the family. So as they distinctively known as Melayu Jawa. They who life in Johor, predominantly coming from eastern part of Java Island particularly from Ponorogo district.

Javanese are among people who easily mingle and adapt to the local society, though they are aware and taking precaution in adopting new tradition. While there are Javanese culture performance that they do not practice anymore, there are some that remain exist and performed routinely. Those are performance like kuda kepang, wayang kulit, barongan, reoq and ludrok. Some of those cultural performance have traces of Hindu religion influence such as in the kuda kepang but has been adpted to some Islamic value. It is believed that the nine legendary preacher in Java Island known as Wali Songo were using this dances to attract local indigeneous Javanese to come and listen to the Islamic teaching. The people in rural Java Island use this Kuda Kepang (or Jaran Kepang in Javanese language) dance performed during the any social gathering. In Johor, this Kuda Kepang remain popular today in district like Batu Pahat, Parit Raja, Seri Medan and Senggarang, (Etnik Jawa, 2013).

Another Javanese art performance called Barongan is local version of the fable based on the bibilcal story of Prophet Sulaiman AS who able to communicate and talk to animals. In Johor, among those group that activelty performed is Kumpulan Barongan Seri Wahyuni from Parit Bingan of Parit Raja who believed coming from Java through Riau Lingga in Sumatera Island. Traditional leather 
puppet performance or Wayang Kulit Jawa also still performed. But today only small number of performance group that remain active. While Reog that are part of Persembahan Barongan performance may be performed in shorter version. Among the active group are Kumpulan Setia Budi, Parit Nipah, Parit Raja, (Etnik Jawa, 2013).

As Kuda Kepang remain exist and performed in Johor and some othe Malaysian state, most of the Javanese cultural performance is no longer performed as the public response are also diminishing. The local Kuda Kepang has been mentioned coming from Kelantan State, some study need to confirm this. There are some differences between those Kuda Kepang performance. The Kuda Kepang performance has been labelled as dangerous for some people, as it performed by dancer who performed in trance and sometime under the influence of traditional alcohol. This kind of spirits involvement in the dance sometime have effect to the audience who become influenced and come into trance as well. Therefore, the Mufti of Johor, who is the highest Islamic religious authority in Johor has stated that this kind of Kuda Kepang is prohibited to perform in Johor. Somehow, some other people who want to maintain the tradition also seeks trong evidence to avoid it. Some evidence is that the Kuda Kepang performance in Johor does not practice reading of mantera or animistic-spell which is against Islamic teaching and may damage the performance and audience aqidah or fundamental belief (in Islam).

Other cultural perfomance remain exist in Johor is the Wayang Kulit or leather puppet show. Mostly performed merely for tourist attraction and not for the tradition. Othe more complicated cultural performance which involved a lot of talented artists or performer like Barongan, reog and ludrok are even least to be found anymore in Johor. One of the reason is the practocality and the present of communication technology that can deliver more practical and enjoyable entertainment especially for the younger generation.

\subsection{SIGNIFICANCE OF IDENTITY IN THE JAVANESE LIFE AND THE CULTRUAL CHANGE}

The Javanese are maintaining their community identity. In the Javanese community, ever since the early age of small childrens of boys and girls, are treated differently. The boys was told to behave as a true man while the girls are always reminded to be polite. The boys are not encouraged demonstrate emotional attitude, while the girls are discourage being aggressive. Boys will be asked to assist his father like gardening or carpentry, while girls are taught to help the mother doing housework such as cleaning, cooking, etc..

In the Javanese community, men are considered as a source of power in a society. Community leadership positions such as the appointment of Pak Lurah (Head of A village) must be held by men. By faith, men being more mature and not as emotional as women. A woman who have sensitive soul, may cause them to be emotional in making a decision. The men were stronger also makes them very important people and appointed as head of the family. Physical strength with a well-built physique bloom, manly, masculine mighty hard and be an important contributor in the line of duty as a search of sustenance. They support living for the family and take care of the welfare and safety of his family, (Hisham, 2012).

Javanese Men may look stern from the outside, but soft on the inside. They will not scold their children openly, but through his wife. Javanese Women are polite, soft and caring towards their husbands and their children. Thus, children are friendly and affectionate to the mother than the father. A husband and wife will be very obedient. Not only they obey, but even glorify their husband. This is important because the Java community strives to maintain identity, customs and culture, and they will not be forgotten in time and constantly evolving over time.

Among the famous cultural performance in society that has been implemented in Java and the Malay community is Barongan and Kuda Kepang. No doubt of both, these cultures had become famous at the old times. But not anymore, nowadays because of the improvement of technology to build, to some extent undermine the culture of art like this. The dance is a folk dance that depicts the stories in the days of Nabi Sulaiman a.s with animals, that can talk. Supposedly, a tiger was seen a peacock's tail opening it wide. When she saw the tiger, the peacock jumped on the head of a tiger, and 
they keep dancing. Suddenly a guard commander named Garong, who guarding the Putri Raja or Princes entourage passing through this area. Amused by those two dancing animal, this commander step down from his horse and start dancning with the animal. This dance remain performed in area like Batu Pahat, Johor and in Selangor state. Among the musical instrument used for the Barongan dance are gong, gendang and angklung. The Barongan dance believed to start being performed first in Malaysia around 1722 by the Javanese muslim. During the Riau-Lingga kindom vanish, many of the kindong follower take refuge to Johor Malaysia and expanding the Malay culure based on Islam. In Indonesia itself people consider Barongan dance is a plagiarism form of Indonesian traditional dance called Hindu's Reog of Ponorogo, as both dances similar tune and acts, including the main dances like topeng dadag, Merak (peacock) feather on top of the tiger' head (Tun Sheikh, 2012).

This fact is denied by the Ponorogo people, who assumed migrants who set foot on Malaysia had practiced their own culture arts way before Indonesia's existence, as culture thieves. The dadak merak figure resembled the Hindu ceremony kavadi during the celebration of Thaipusam. The Barongan dance is also quite intriguing, for there is a tradition that presented the Barongan after the Kuda Kepang (Braided Horse) dance. This is because the Kuda Kepang Dance is believed as a way to attract a crowd's attention during the spread of Islam in Java. Regarding how the tradition puts the Barongan Dance after the Kuda Kepang Dance might just be evidence to the importance of the Barongan Dance during the spread of Islam at the time.

The dance known as Barongan presented in Malaysia, mainly in Johor, quite resembles the Reog dance. Mainly, they don the same props such as the Dadak Merak mask, a tiger head-shaped mask with tufts of peacock feathers on top. This infuriates the Ponorogo citizens, prompting them to protest towards Malaysia and claim that Malaysians had plagiarized their Reog dance. A Reog dancer also threatened dadak merak deliveries to Malaysia. The Kuda Kepang is a traditional Malay dance. It is also the traditional heritage of Islamic-influenced Javanese culture. The Javanese traits are prominent on the dancers' clothes, and the Islamic elements show within the choreography storyline, which tells the battle endured by the Prophet (PBUH) and his friends. (Hisham, 2012)

It has been said that this dance is introduced by Islamic clerics as a way to attract locals to gather around and watch their presentation. These clergymen will preach their teachings either before or after their presentation. The Kuda Kepang dance is very much enjoyed by the Johor people, mainly those of Javanese descent. The eponymous braided horse is usually crafted to look like a legless horse. It's made from woven bamboo or animal leather, tinted for attraction. Usually there should be 10 to 15 dancers with one leader.

In the first phase, all the dancers' movements are orders from the rope-wielding maiden to begin the play. This dance is usually performed in gatherings to further enliven the atmosphere for welcoming nobles and public figures, weddings or any celebratory events. Back in the days there were many restrictions for those who watched the braided horse dance, for example, never insult the dancers or those who do will receive bad luck.

There had been different opinions regarding the dance's origins. One traced its sources to the Wali Songo, who lived in Javanese lands in the 15th century. In efforts of spreading Islam in the Javanese inland, Wali Songo had faced difficulties approaching the villagers. They suddenly had the idea to dance around while riding a horse. As time passes, they had began to use leather or bamboo in place of live horses. Another opinion stated the origins of this dance had something to do with Saidina Ali. The braided horse dance was born by an attempt of reiterating his army's steps. (Hisham, 2012)

The Malaysian version of the Barongan dance, along with the Kuda Kepang dance, are performed at Batu Pahat area, Johor. But nowadays this dance isn't getting enough attention and rarely performed due to accusations of mystical influences that could endanger people, eventhough the dance itself is a form of harmless entertainment besides studying about religion. The accusations were untrue and not researched thoroughly. Indirectly, this cultural change is said to maintain the prosperity of Malaysian citizens and bringing ukhuwah (similarities) closer by diving inside Asia's Malay culture. Other than that, it decreases the risk of conflict due to tribal and societal differences. (Rostam Hamzah, 2013) 
The Javanese people also posess their own artistic and technological traits. They have various technology in manufacturing. For example, the makings of braided horse, barongan, musical instruments, kempling and cloth. Manufacturing the braided horse involve weaving, To make these, woven bamboo sheets are used. Initially they used woven pandan leaves, now there are ones being made from layered planks or cow leather. Stereotypically these braided horses are black with yellow tufts. Some are even wrapped in velvet, and these are usually for high-end performances. The lead braided horse is usually black in color. (Amin Sweeney, 2011)

It is quite different from the barongan that is synonymous with the mask used in the dance. This performance is usually played with kenong and gendang. These are made with the same type of wood as Reog Ponorogo, but without peacock feathers. Usually they would use dadak wood and cattle leather. The Barongan is more towards a religious theme whereas the Reog Ponorogo dance tells a story about determination. The building process usually takes about two to three days.

Besides that, the Javanese are also well known for their wayang kulit (leather puppets), wherein the puppets are hand-crafted by the pupeteers. This wayang kulit industry has been stated to be almost forgotten in Malaysia (e.g. Kelantan) due to their advanced film industry which has sort of taken over the wayang kulit industry. Moreover, some stated the wayang kulit possess religious traits and linked to sorcery which would deem unluckiness, especially towards Muslims (Amin Sweeney, 2011).

A famous/recognizable wayang kulit technology here is the Javanese wayang kulit (Purwa), which is said to hail from the islands of Java, Indonesia. These leather puppets present characters from the stories of Mahabratha and Panji. Initially, they are introduced in Kelantan by Tok Dalang Melayu after studying the techniques used by Tok Dalangs in Java. Among these characters are Sang Kula, Raden Galoh Cendera Kirana, Arjuna, Sang Dewa and Raden Inu Kartapati.

Wayang Purwa is found in the Southern region of Pantai Barat Semenanjung (Johor) and centered around an episode of the book of Mahabrata and the stories of Panji. Every form and type of these puppets are Javanese-influenced. In Johor and Kelantan they've underwent a transformation suiting the locals' tastes more. The difference withing these Johor and Kelantan puppets lies on the shape of the eyes. Among the musical instruments played in Wayang Purwa are the big gong (gong Agong), the Suwukan Gong, Gambang, Kempul, Kenong, gender, Slentem, Demung, Saron, Peking (Saron Penerus), Ketok / Kompang, Rebab and Gendang. Among the songs played are Lagu Bertabuh, Perang Seri Rama, Kabar Manja, Buluh Seruas, Pandan Wangi and such. The wayang is presented in the Javanese language, occasionally slipping in some local Malay dialects. (Tun Sheikh Engku Bendahara: 2012)

The figure who responsible in creating the wayang kulit for performance is the Dalang himself. The Dalang need to poses special traits such as creative and wise, especially when he need to convey the message through their puppet character. These character are also need to be represented in artistically beautiful and suit to the story.

\subsection{CONCLUSION}

Javanese society put weight on the ethics and exemplary models. They are putting politeness and tolerance at utmost importance. Their characters can easily be recognized from their soft-spoken language and from their low-key mannerism. Their present in Malaysia should intermingling and accepted as part of single Malaysian community for together contributing to Malaysian nation.

Meanwhile, the multicultural assimilation of the Javanese into Johor create cross-cultural enrichment as well as several challenges. However, these Javanese culture should have be well adapted, as the weaknesses will be be resolved and improved by themselves. Their population in Johor are already significant and most of them already become Malaysian citizen. The Javanese technology and social conducts has been accepted and blended in to the locals.

Envisioned that in the future, this cross-cultural relationship will bring bring more goodness and continuous social harmony for both the Javanese and the indigenous Malays in Johor. Should the people takes this opportunity, anticipated that Janavenese cultures can florish side-by-side with the indigenous Malays' cultures. 
The Javanese present in Johor has brought more vatiation and enrichement to the local / indigeneous Malays, especially in the aspect of cultural art. The Javanese Kemplingan, Gamelan and Kuda Kepang cultural art performances remain performed today, and benefit to bring cultural previledge of the Malays as well as Javanese. Even when the Malaysian cultural performance conducted overseas, these Javanese cultural shows were part of them and considered as one of the Malays cultural diversity. Therefore this cultural performance which have divine and religious values as part of cultural heritage, should be embraced and models by the younger generation so will not fading away ("tidak lekang dek panas, tidak hilang dek hujan") and pushed away by current modern technology .

\section{REFERENCES}

Aziz Deraman (2005). Masyarakat dan Kebudayaan Malaysia. Dewan Bahasa dan Pustaka: Kuala Lumpur

Beryle de Zeete (1969). Dance and Drama in Bali. Oxford University Press, Kuala Lumpur. Hai Rozzaman Jalal (2000). Kemplingan: Satu Kesenian Jawa di Johor.

Harun Mat Piah, Inon Shaharuddin, Abd. Rahman dan Siti Zainon Ismail (1980). Tradisi Gamelan di Malaysia. Kertas Kerja Simposium Gamelan Malaysia, Universiti Kebangsaan Malaysia, Bangi

http://ihwan42.blogspot.com/2013/01/sifat-dan-karakter-orang-jawa.html, diakses pada 26 April 2014

Hai Rozzaman Jalal, Kemplingan, 2000

Simuh (2000), Keunikan Interaksi Islam dan Budaya Jawa. Seminar Pengaruh Islam Terhadap Budaya Jawa.

Pucuk Gunung Es Kelisanan dan Keberaksaraan dalam Kebudayaan Melayu-Indonesia, Amin Sweeney, Cetakan Pertama, Julai 2011,Pages 80-83.

Wayang Kulit Purwa Gaya Yogyakarta: Sebuah Tinjauan tentang Bentuk, Ukiran dan Sunggingan, Sunarto, Pages 102-106

Siri Mengenal Budaya 1/2003, Wayang Kulit, Bahagian Pembangunan Kebudayaan dan Kesenian, Kementerian Kebudayaan, Kesenian dan Pelancongan Malaysia, 2003.

Jakim (2012). Seni Islam. Atas talian:

http://www.islamgrid.gov.my/articles/seniislam/pengenalan.php Jennifer Lindsey (1979). Javanese Gamelan. Oxford University Press, Kuala Lumpur.

Kejaraan Negeri Johor (2012). Tarian Tradisional. Atas talian: http://www.johordt.gov.my/pelancongan/page/tarian_tradisional

Khazin Mohd. Tamrin dan Sukiman Bohari (1980). Orang Jawa Pontian: Kedatangan dan Kegiatannya dalam Aspek Sosio-ekonomi dan Politik Tempatan. Malaysina Journal of History, Politics and Strategy Studies, Universiti Kebangsaan Malaysia, Bangi

Norman Parmer (1910-1941). Colonial Labour Policy and Administration: A history of labour in the rubber plantation industry. New York

http://hissham66.blogspot.com/2012/08/kajian-etnik-jawa-di-malaysia.html, diakses pada 19 April 2014

Othman Ahmad (1990). Kemplingan. Bahagian Kebudayaan, Kementerian Kebudayaan dan Pelancongan.

Portal Rasmi Fatwa Malaysia (2009). Fatwa Permainan Kuda Kepang di Negeri Johor. Atas talian: http://www.e-fatwa.gov.my/fatwa-negeri/fatwa-permainan-kuda-kepang-di- negeri-johor

Sahgidon Dirhan (1980). Pusat Kebudayaan Jawa di Malaysia, Semesta.

Salmah Omar (1979). Permainan Tradisi Barongan di Batu Pahat. Latihan Ilmiah, Jabatan 
Mifedwil Jandra / UMRAN - International Journal of Islamic and Civilizational Studies. vol.3, no.3-1 (2016), 01-09

http://sejarah-tunsheikh.blogspot.com/2012/11/normal-0-false-false-false-en-us-X-none.html, diakses pada 19 April 2014

Persuratan Melayu, Universiti Kebangsaan Malaysia, Bangi.

Septy Ruzui (1980). Muzik Gamelan Malaysia dalam Perbandingan dengan Muzik Gamelan Nusantara. Kertas Kerja Simposium Gamelan Malaysia, Universiti Kebangsaan Malaysia: Bangi

Shafie Abu Bakar (1980). Aspek Alat dan Pembuatan Malaysia. Kertas Kerja Simposium

http://rostamhamzah68.blogspot.com/2013/04/etnik-jawa.html, diakses pada 19 April 2014

Gamelan Malaysia, Universiti Kebangsaan Malaysia: Bangi

Sidi Gazalba (1977). Pandangan Islam Tentang Kesenian. Kuala Lumpur: Penerbit PustakaAntara.

Sinar Harian (27 Ogos 2010). Keunikan Kempling: Kesenian Masyarakat Jawa Sejak

Berzaman. Atas talian: http://www.sinarharian.com.my/johor

Tun Sheikh Engku Bendahara (2012). Sejarah Kedatangan Orang Jawa ke Johor. Atas talian: http:

//sejarah-tunsheikh.blogspot.com/2012/11/normal-0-false-false-false-en-us-X- none.html 